\title{
Vegetation Response to a One-Time Spent Drilling Mud Application to Semiarid, Mixed-Grass Prairie
}

\author{
Francis Zvomuya, ${ }^{1}$ Francis J. Larney, ${ }^{2}$ Walter D. Willms, ${ }^{2}$ Ryan K. Beck, ${ }^{3}$ and Andrew F. Olson ${ }^{3}$ \\ Authors are ${ }^{1}$ Associate Professor, Department of Soil Science, 362 Ellis Bldg, University of Manitoba, Winnipeg, Manitoba, Canada R3T 2N2; \\ and ${ }^{2}$ Research Scientists and ${ }^{3}$ Research Technicians, Agriculture and Agri-Food Canada, Lethbridge Research Centre, 5403 1st Ave S, Lethbridge, \\ Alberta, Canada T1J 4B1.
}

\begin{abstract}
Landspraying while drilling (LWD) is an approved disposal method for water-based drilling mud (WBM) systems in western Canada. The mud is applied either on cultivated land, where it is incorporated by cultivation, or on vegetated land where it is not incorporated. This study examined the effects of summer WBM application $\left(0,15,20,40\right.$, and $\left.80 \mathrm{~m}^{3} \cdot \mathrm{ha}^{-1}\right)$ on native vegetation properties. Our results indicated that LWD increased bare ground but decreased lichen cover at the $80 \mathrm{~m}^{3} \cdot \mathrm{ha}^{-1}$ rate relative to the untreated control. Nitrogen $(\mathrm{N})$, sulfur $(\mathrm{S})$, and magnesium $(\mathrm{Mg})$ concentrations in aboveground plant tissue increased with increasing LWD rate in samples taken $45 \mathrm{~d}$ after WBM application, but these differences disappeared $1 \mathrm{yr}$ after treatment. Increase in tissue concentration of phosphorus (P) with LWD rate, however, was only detected $3 \mathrm{yr}$ after LWD. Nonetheless, these changes in tissue chemistry were not associated with significant changes in biomass yield or species composition. Overall, our results suggest that single WBM applications at rates $\left(\leq 20 \mathrm{~m}^{3} \cdot \mathrm{ha}^{-1}\right)$ commonly used in western Canada, if properly managed, are unlikely to adversely affect native prairie vegetation.
\end{abstract}

\section{Resumen}

El rociado del terreno durante la perforación (LWD) es un sistema aprobado de eliminación de lodo en sistemas de perforación basados en el uso de agua (WBM) en el oeste de Canadá. El lodo puede aplicarse a tierras arables, donde es incorporado al suelo mediante la labranza, o a tierras con cobertura de vegetación donde no es incorporada al suelo. Este estudio examinó el efecto de la aplicación de WBM durante el verano $\left(0,15,20,40\right.$, y $\left.80 \mathrm{~m}^{3} \cdot \mathrm{ha}^{-1}\right)$ sobre las propiedades de la vegetación nativa de la pradera. Nuestros resultados indicaron que el LWD incrementó el suelo desnudo pero provocó una disminución en la cobertura de líquenes comparado con el testigo cuando la aplicación fue de $80 \mathrm{~m}^{3} \cdot \mathrm{ha}^{-1}$. La concentración de nitrógeno (N), azufre (S), y magnesio $(\mathrm{Mg})$ en los tejidos vegetales aéreos aumentó con incrementos en la dosis de LWD en muestras tomadas 45 días luego de la aplicación del WBM, pero estas diferencias desaparecieron un año después del tratamiento. El aumento en la concentración de fósforo (P), sin embargo, sólo se detectó tres años después del LWD. No obstante, estos cambios en la composición química de los tejidos no estuvieron asociados a cambios significativos en la producción de biomasa o en la composición de especies. Nuestros resultados sugieren que en general, una única aplicación de WBM en $\mathrm{dosis}\left(\leq 20 \mathrm{~m}^{3} \cdot \mathrm{ha}^{-1}\right)$ comúnmente usadas en el oeste de Canadá, no tendría un efecto negativo sobre la vegetación de la pradera si la misma es manejada correctamente.

Key Words: biodiversity, energy exploration, hydrocarbon extraction, native rangeland, oil and natural gas

\section{INTRODUCTION}

Drilling muds (or fluids) are used during exploratory and development drilling for oil and natural gas to lubricate and cool the drill bit and control subsurface wellbore pressure (Neff et al. 1987; Ukeles and Grinbaum 2004). They also function to remove drilled-out rock cuttings from the well, clean the bit and the bottom of the hole, and stabilize the wellbore. Water-based drilling muds (WBMs) are the most commonly used mud system for shallow gas wells (250-650 m deep) in western Canada. The WBMs consist of fresh water as the base and bentonite to provide viscosity and create a filter cake on the borehole wall to control fluid loss (Bloys et al. 1994). Polymers, such as partially hydrolyzed polyacrylamide, are sometimes added to increase

Research was funded in part by EnCana Corporation, Calgary, Alberta, Canada. This paper is Lethbridge Research Centre contribution no. 387-10004.

Correspondence: Francis Zvomuya, Dept of Soil Science, 362 Ellis Bldg, University of Manitoba, Winnipeg, Manitoba, Canada R3T 2N2. Email: zvomuyaf@cc.umanitoba.ca fluid viscosity, inhibit clay and shale swelling and sticking, and flocculate drilled solids. Inorganic chemical additives include sodium hydroxide (caustic soda) and potassium hydroxide (caustic potash) to control (increase) mud $\mathrm{pH}$ and minimize corrosion of the drill pipe, casing, and rig equipment, and sodium carbonate (soda ash) to reduce water hardness.

As drilling muds circulate down the hole and back up to the surface, some of the liquid and solid materials end up as drilling waste. Drilling waste consists of the drilling fluid that was originally used and the formation cuttings (e.g., clay and rock pieces) that were transported back to the surface. A typical shallow gas well in southern Alberta commonly generates approximately $68 \mathrm{~m}^{3}$ of spent drilling mud (EnCana Corp, unpublished data, 2006). Various methods can be used to dispose of drilling waste, including underground injection, onsite burial (pits and landfills), land treatment (land spreading, land farming, and road spreading), evaporation from sump storage, surface discharge, recycling, and off-site disposal at commercial disposal facilities (Veil 1997). Choice of disposal 
method is determined by waste characteristics, government regulations, and the availability and cost of commercial off-site disposal facilities.

In western Canada, landspraying while drilling (LWD) is a commonly used disposal approach for WBMs (Alberta Energy and Utilities Board 1996). LWD involves collection of drilling wastes from approved mud systems (fresh water gel, gypsum water, or nitrate gypsum water) during the drilling operation and their prompt spraying on the soil surface of nearby lands at low application rates. The WBMs are landsprayed at maximum rates of $40 \mathrm{~m}^{3} \cdot \mathrm{ha}^{-1}$ in summer or $20 \mathrm{~m}^{3} \cdot \mathrm{ha}^{-1}$ in winter or on frozen ground (Alberta Energy and Utilities Board 1996). Additionally, total loadings of solids from LWD must not exceed $6 \mathrm{Mg} \cdot \mathrm{ha}^{-1}$. Spraying techniques may include the use of vacuum trucks with spread plates or similar equipment. On cultivated land, LWD is normally followed by soil incorporation. However, on native rangeland, incorporation is obviously not an option and the drilling mud remains on the soil surface or vegetation canopy.

Native grasslands are among ecosystems on the Canadian prairies that are most pressured by various land uses. It is estimated that only $24 \%$ of the Mixedgrass and Dry Mixedgrass Natural Subregions of western Canada remains, as a result of fragmentation by urbanization, industrial development, livestock grazing, or conversion of rangeland to annual cropping or seeded pastures (Environment Canada 2007). Native plant species could conceivably show different patterns of response to drilling mud application, resulting in changes in plant community composition and structure. As a result, there is a need for more information on the potential impacts of LWD on these ecosystems in order to prevent further degradation.

Potential benefits of LWD include elimination of the need for local or remote sumps to store drilling waste, which in turn, reduces truck traffic and disturbance on native prairie associated with drilling mud haulage from wellsites to sumps. On the other hand, LWD may adversely affect vegetation through plant uptake of toxic components or excess coating or burial of the vegetation (which could inhibit photosynthesis or delay flowering or seed set). Detrimental effects on native prairie soil properties have recently been reported. For example, studies in western Canada indicate that moderate to high rates $\left(40\right.$ and $\left.80 \mathrm{~m}^{3} \cdot \mathrm{ha}^{-1}\right)$ of LWD can reduce the nearsaturated hydraulic conductivity of sandy loam soils under native prairie (Zvomuya et al. 2009). Results from a related study showed that LWD rates of $40 \mathrm{~m}^{3} \cdot \mathrm{ha}^{-1}$ or higher resulted in lower ground surface albedo leading to elevated surface heat flux and root zone temperature in native prairie soils during summer (Zvomuya et al. 2008).

The objective of this study was to assess the impacts of drilling mud application on native prairie vegetation. Specifically, the study examined 1) changes in plant canopy cover, 2) biomass production, and 3) total nutrient and elemental concentration of native plant species following one-time, summer applications of WBM.

\section{METHODS}

\section{Site Description}

The study was located within the Canadian Forces Base (CFB) Suffield Range (lat $50^{\circ} 15^{\prime} \mathrm{N}$, long $111^{\circ} 12^{\prime} \mathrm{W}$ ) near Medicine
Hat, Alberta. The Range is comprised of $2690 \mathrm{~km}^{2}$ of biologically diverse native prairie landscape and lies within the Dry Mixedgrass natural subregion of Alberta. The area has a typical continental climate with cold winters, warm summers, and low precipitation. Monthly mean temperatures (19712000) vary from $-13^{\circ} \mathrm{C}$ in January to $20^{\circ} \mathrm{C}$ in July and annual precipitation averages $318 \mathrm{~mm}, \sim 70 \%$ of which is rainfall. Due to the warm temperatures and high wind speed throughout the summer, evaporation is high $(\sim 365 \mathrm{~mm}$ annually; EnCana Corp, unpublished data), resulting in an annual moisture deficit of nearly $50 \mathrm{~mm}$.

The soil at the site is a Typic Haploboroll of sandy loam texture. Plant canopy cover is dominated by the grasses Bouteloua gracilis (Kunth) Lag. ex Griffiths and Hesperostipa comata Trin. \& Rupr. while Sphaeralcea coccinea (Nutt.) Rydb. was the dominant forb. The site had not been grazed by cattle since fall 2003. Oil and gas development at CFB Suffield commenced in 1975 and to date, more than 9000 natural gas and at least 500 oil wells have been drilled (EnCana Corp, unpublished data).

\section{Experimental Design}

The experiment consisted of 45, 100-m long $\times 12-\mathrm{m}$ wide contiguous plots, which occupied an area of $100 \times 540 \mathrm{~m}$. Conventional landspraying equipment $\left(18 \mathrm{~m}^{3}\right.$ vacuum truck) was used to apply the drilling mud in late June 2004, 2005, and 2006. The plot length included a $25-\mathrm{m}$ headland at each end to allow start-up of the vacuum trucks to attain correct forward speed and shut-down at the end of the plot.

We used a staggered-start design (Loughin et al. 2007), which included three replications in time $(2004,2005$, and 2006) and triplicate LWD rate treatments $(0,15,20,40$ and $80 \mathrm{~m}^{3} \cdot \mathrm{ha}^{-1}$ ) in each year arranged in a randomized complete block design. Fifteen plots were treated in each of the $3 \mathrm{yr}$ for a total of 45 plots.

\section{Drilling Mud Application}

The spent drilling mud used in the experiment came from different wells and was derived from a WBM system, which was an aqueous suspension of bentonite (primarily sodium montmorillonite) in freshwater. Prior to mud application on the plots, application rates were verified using Harmonie disposable underpads (padded area $48.5 \times 35 \mathrm{~cm}$; weight $24.2 \mathrm{~g}$; SCA Hygiene Products, Drummondville, Québec). The spreading width of the vacuum truck was adjusted to $12 \mathrm{~m}$, which was the width of each individual plot. Calibration entailed laying eight underpads on the ground in each of two parallel 12 -m wide rows that were $10 \mathrm{~m}$ apart. The vacuum truck was then driven across the middle of and perpendicular to the rows, starting $25 \mathrm{~m}$ from the first row, adjusting the truck speed and pump pressure until the target mud rate was achieved. The rate after each pass was determined from the net weight gain of the mudsoaked underpads and the specific density of the mud. The speed and pressure corresponding to each rate was noted for use in the appropriate plots. During application to plots, actual mud rates applied were verified by placing underpads on the ground surface in the spread path of the drilling mud application. Two 12-m rows of eight underpads each were placed at the $25-\mathrm{m}$ mark from each end of the plot. One or 
more passes were made down the centre of the plot while making sure the mud spray did not extend to adjacent plots. Actual rates applied were then calculated as described for the calibration above.

\section{Drilling Mud Characterization}

Chemical Analysis. Drilling mud samples were taken in duplicate from each of the 21 truckloads for chemical and physical analysis. Multi-element concentrations were determined by inductively coupled plasma optical emission spectrometry (ICP-OES; Spectro Analytical Instruments, Kleve, Germany) following digestion of freeze-dried mud subsamples according to US Environmental Protection Agency (USEPA) Method 3050B (USEPA 1996). The actual oven-dry weight of the subsamples ranged from $0.13 \mathrm{~g}$ to $2.4 \mathrm{~g}$ (mean $0.4 \mathrm{~g}$ ) per $50 \mathrm{~mL}$ digest, reflecting differences in mud density among truckloads. Elemental concentrations are reported on a dry weight basis.

For determination of major analyte and trace element concentrations in solution, the drilling mud was centrifuged and the supernatant filtered through a Whatman \#1 (11 $\mu \mathrm{m})$ filter paper. Electrical conductivity (EC) and $\mathrm{pH}$ of the extract were measured with a $\mathrm{pH} /$ conductivity meter (Accumet $\mathrm{pH}$ meter 50; Fisher Scientific, Hampton, $\mathrm{NH})$. Dissolved $\mathrm{N}\left(\mathrm{NO}_{3}{ }^{-}\right.$ $\mathrm{N}+\mathrm{NH}_{4}-\mathrm{N}$ ) concentration was determined in the supernatant by micro-segmented flow analysis using an Astoria 2 Analyzer (Astoria-Pacific International, Clackamas, OR). Multi-elemental concentrations in the extract were determined by ICP-OES as described above. Sodium adsorption ratio (SAR) was calculated from $\mathrm{Na}, \mathrm{Ca}$, and $\mathrm{Mg}$ concentrations from the ICP analysis.

Mud Density. The density of drilling mud from each truckload was measured using a mud balance (Wyo-Ben, Inc, Billings, MT). Dry bulk density (DBD; i.e., the weight of dry solids per unit volume of wet mud) was calculated by substituting the measured mud density into the following equation:

$$
\begin{aligned}
\operatorname{DBD}\left(\mathrm{kg} \cdot \mathrm{m}^{-3}\right)=\{ & {\left[\text { measured mud density }\left(\mathrm{kg} \cdot \mathrm{m}^{-3}\right)\right.} \\
& \left.\left.-1000\left(\mathrm{~kg} \cdot \mathrm{m}^{-3}\right)\right] \times 2.65\left(\mathrm{~g} \cdot \mathrm{cm}^{-3}\right)\right\} \\
& /\left[2.65\left(\mathrm{~g} \cdot \mathrm{cm}^{-3}\right)-1\left(\mathrm{~g} \cdot \mathrm{cm}^{-3}\right)\right]
\end{aligned}
$$

where measured mud density is equal to specific gravity $\left(\mathrm{g} \cdot \mathrm{cm}^{-3}\right) \times 1000,2.65$ is the particle density of solids, and $1000 \mathrm{~kg} \cdot \mathrm{m}^{-3}\left(=1 \mathrm{~g} \cdot \mathrm{cm}^{-3}\right)$ is the density of water.

\section{Vegetation Measurements}

Canopy cover for each species was visually estimated in July each year using the percentage cover method of Daubenmire (1968) in two transverse transects situated $40 \mathrm{~m}$ from either end of each plot. Canopy cover (\%) was assessed in six quadrats per transect, avoiding vacuum truck wheel tracks. The data were used to compute species richness $(S)$, species evenness $(E)$, and species diversity (Shannon-Wiener Index, $H^{\prime}$ ). Plant species in the plots were classified into two growth forms: grasses/grass-like and forbs. Seed-head density of dominant grasses was determined by counting the number of inflorescences within each $0.25 \mathrm{~m}^{2}$ quadrat.
Visual estimates of ground cover were conducted as well, and included the basal cover of live vegetation, little club moss, lichen, litter, or bare ground. Percent bare ground was calculated as the difference between $100 \%$ and the sum percent of areas covered by moss, lichen, and litter plus the basal area of live vegetation (Willms et al. 2002).

Standing vegetation was clipped at ground level each year from six $0.5 \times 0.5 \mathrm{~m}$ areas within each plot (outside the quadrats used for plant cover assessment), avoiding areas that had been clipped the previous year. Surface litter was handraked from a $0.5 \times 0.2 \mathrm{~m}$ area inside two of the six clipped quadrats. Standing biomass and litter samples were stored separately and oven-dried to a constant weight at $70^{\circ} \mathrm{C}$. A subsample consisting of $10 \%$ of the total standing biomass from each plot was hand-sorted into annual production from the current year (live standing biomass or annual net primary production [ANPP]) and biomass from previous years (dead standing biomass; Willms et al., 2002). These were separately weighed and ground in a Wiley mill using a 20-mesh screen prior to chemical analysis. The proportions of live biomass and standing dead biomass were applied to the total biomass yield from each plot to estimate ANPP and standing litter as described by Willms et al. (2002).

Determination of Ash-free Dry Weight. Ash concentration of all plant material was determined to eliminate the variation in dry weight that might arise from drilling mud application. Ovendry subsamples from each plot were composited, thoroughly mixed, and weighed to determine "dry weight." Coarse plant material was separated from any fines settled at the bottom of the bowl. The weight of the fine material was recorded (it was assumed dead:green ratio was similar to that in coarse material). A subsample $(\sim 10 \mathrm{~g})$ from the coarse material was separated into live and dead (standing) biomass, which were then weighed separately. The green and dead biomass subsamples were ashed in a muffle furnace at $650^{\circ} \mathrm{C}$ for $24 \mathrm{~h}$. The ash residue (inorganic remains) was weighed, and ash-free dry weight (AFDW) was obtained by subtracting the ash weight from the corresponding oven-dry weight. All dry matter yields and chemical analyses on the rest of the biomass sample were expressed on an AFDW basis.

Plant Tissue Analysis. Plant samples were oven-dried at $70^{\circ} \mathrm{C}$ before chemical analysis. Fine-ground samples $(<0.15 \mathrm{~mm})$ were analyzed for total $\mathrm{C}$ and $\mathrm{N}$ by dry combustion using an automated CNS analyzer (Carlo Erba, Milan, Italy). Total P, S, and trace element ion concentrations were determined following digestion of 0.25 -g subsamples with nitric acid $\left(\mathrm{HNO}_{3}\right)$ and hydrogen peroxide $\left(\mathrm{H}_{2} \mathrm{O}_{2}\right)$. Simultaneous analysis of the elements was performed by ICP-OES (Spectro Analytical Instruments).

\section{Data Analysis}

Canopy and basal cover data were $\log _{\mathrm{e}}(\mathrm{x}+10)$-transformed to meet assumptions of normality (Shapiro Wilks test) and equality of variances (Levene's test). These and the nontransformed diversity index $\left(S, E\right.$, and $\left.H^{\prime}\right)$ data were analyzed using PROC MIXED for repeated measures in SAS (Littell et al. 1996; SAS Institute 2005), with time elapsed (days after 
Table 1. Measured pH, electrical conductivity (EC), sodium adsorption ratio (SAR), water, and solids content of drilling muds applied during the $3 \mathrm{yr}$.

\begin{tabular}{lccccc}
\hline Parameter & $\mathrm{pH}$ & $\mathrm{EC}$ & $\mathrm{SAR}$ & $\mathrm{H}_{2} \mathrm{O}$ & Solids \\
\hline Minimum & 7.17 & 2.50 & 7.98 & 620 & 105 \\
Maximum & 10.8 & 9.97 & 57.2 & 895 & 380 \\
Mean & 8.12 & 4.95 & 19.1 & 764 & 236 \\
Median & 7.50 & 4.13 & 18.1 & 767 & 233 \\
\hline
\end{tabular}

treatment [DAT]) as a repeated measures effect with the first order autoregressive covariance structure. Year was also included as a repeated measures effect in the model that allowed for random variations over time (Loughin et al. 2007). The Tukey multiple comparison procedure was used for all pairwise comparisons. Effects were considered significant if $P \leq 0.05$.

\section{RESULTS}

\section{Precipitation}

Weather data were obtained from the CFB Suffield weather station. Annual rainfall totals were 179, 332, 221, and $200 \mathrm{~mm}$ for 2004, 2005, 2006, and 2007, respectively. Corresponding annual snow totals were 86, 52, 92, and $62 \mathrm{~mm}$. In 2005, which was the wettest of the $4 \mathrm{yr}, 156 \mathrm{~mm}$ of rainfall were received in June alone, compared with 34-89 $\mathrm{mm}$ for the other $3 \mathrm{yr}$. The long-term mean rainfall total for June at Suffield is $58 \mathrm{~mm}$. Of the total rainfall received in June 2005, $27 \mathrm{~mm}$ were recorded within a day following mud application. In contrast, rainfall amounts within $4 \mathrm{wk}$ of mud application were minimal in 2004 and 2006.

\section{Drilling Mud Rates}

The measured mud rates applied using vacuum trucks during the $3 \mathrm{yr}$ averaged 14, 18, 42, and $90 \mathrm{~m}^{3} \cdot \mathrm{ha}^{-1}$ for target rates of $15,20,40$, and $80 \mathrm{~m}^{3} \cdot \mathrm{ha}^{-1}$, respectively, indicating reasonable accuracy $(93 \%, 90 \%, 105 \%$, and $113 \%$ of target rates, respectively), with an overall coefficient of variation of $12.3 \%$. Our calibrations indicated that at a pumping pressure of $69 \mathrm{kPa}$ at $1200 \mathrm{rpm}$, truck speed ratios corresponding to $4 \mathrm{H}, 3 \mathrm{H}$, and $1 \mathrm{~L}$ were associated with mean mud application rates of $14.5 \pm 0.5,19.2 \pm 2.0$, and $29.4 \pm 2.2 \mathrm{~m}^{3} \cdot \mathrm{ha}^{-1}$. We were unable to attain rates $>30 \mathrm{~m}^{3} \cdot \mathrm{ha}^{-1}$ in one pass with a spread width of $12 \mathrm{~m}$ in this study, thus necessitating multiple passes (in immediate succession) for the 40 (two passes at $3 \mathrm{H}$ ) and 80 (two passes at $1 \mathrm{~L}$ and one pass at $3 \mathrm{H}$ ) $\mathrm{m}^{3} \cdot \mathrm{ha}^{-1}$ rates. This partly explains the lower accuracy associated with the 40 and $80 \mathrm{~m}^{3} \cdot \mathrm{ha}^{-1}$ rates.

\section{Drilling Mud Properties}

Specific density of the drilling mud ranged from 1.08 to $1.26 \mathrm{~g} \cdot \mathrm{cm}^{-3}$ in $2004,1.07$ to $1.20 \mathrm{~g} \cdot \mathrm{cm}^{-3}$ in 2005 , and 1.13 to $1.22 \mathrm{~g} \cdot \mathrm{cm}^{-3}$ in 2006 . This variability was expected because the mud came from multiple wells since a single well could not supply enough mud for all plots. Filtrate $\mathrm{pH}, \mathrm{EC}, \mathrm{SAR}$, water content, and solids content of drilling muds are presented in Table 1, while total and available $\mathrm{N}$ concentrations are presented in Table 2. Based on the available $\mathrm{N}$ concentrations, a target LWD rate of $20 \mathrm{~m}^{3} \cdot \mathrm{ha}^{-1}$ would add available $\mathrm{N}$ of up to $20 \mathrm{~kg} \cdot \mathrm{ha}^{-1}$. Concentrations of other major nutrients, minor nutrient elements, and $\mathrm{Na}$ are presented in Table 2, while the rest of the trace elements are presented in Table S1. ${ }^{1}$ These data indicate a wide variability in elemental concentrations, likely reflecting the vertical and spatial variation in the distribution of these elements in the different formations drilled, as well as, in some cases, varying amounts of additives applied to the muds.

\section{Vegetation Properties}

Drilling mud rate had a significant effect on only two of the six basal cover classes: lichen and bare soil (Table 3). Lichen basal cover was significantly lower at $80 \mathrm{~m}^{3} \cdot \mathrm{ha}^{-1}(0.35 \%)$ compared to the control $(1.76 \%)$ but differed little among the rest of the rates. The opposite effect was observed for bare soil exposure, which was highest at the $80 \mathrm{~m}^{3} \cdot \mathrm{ha}^{-1}$ rate $(6.12 \%)$ vs. the control $(4.1 \%)$. All other basal cover classes were unaffected by LWD rate and none of the six were affected by time of sampling.

Canopy coverages for the major grass and grass-like species were dominated by B. gracilis (mean 41\%) and H. comata (31\%) followed by Carex spp. (15\%; Table 4). Other major species were Koeleria macrantha (Ledeb.) Schult., Pascopyrum smithii Rybd., and Calamagrostis montanensis Scribn. ex Vasey, which accounted for 3\%, 2\%, and $1 \%$ of the canopy cover, respectively. Drilling mud application had no significant effect on any of the species, but temporal variation was evident for $H$. comata and C. montanensis. H. comata canopy cover was highest 45 and 410 DAT while that for C. montanensis was highest 45 DAT. Drilling mud rate and application time effects were significant only for $K$. macrantha inflorescence density for which the inflorescence density was higher at the $40 \mathrm{~m}^{3} \cdot \mathrm{ha}^{-1}\left(1.12\left[0.25 \mathrm{~m}^{2}\right]^{-1}\right)$ compared with the control $\left(0.64\left[0.25 \mathrm{~m}^{2}\right]^{-1}\right)$ and significantly higher at the $775(3.01$ $\left.\left[0.25 \mathrm{~m}^{2}\right]^{-1}\right)$ DAT than at any other sampling time $(0.38-0.85$ $\left.\left[0.25 \mathrm{~m}^{2}\right]^{-1}\right)$.

Dominant forb species were $S$. coccinea $(3.6 \%$ of total canopy cover, averaged across drilling mud rates), Artemisia frigida Willd. (2.1\%), Phlox hoodii Richardson (0.74\%), Plantago patagonica Jacq. (0.4\%), and Erigeron caespitosus Nutt. (0.2\%; Table 5). E. caespitosus cover at $1140 \mathrm{~d}$ after treatment was significantly higher at $15 \mathrm{~m}^{3} \cdot \mathrm{ha}^{-1}(1.02 \%)$ than at all other rates $(<0.01 \%)$. Rate effects at dates before 1140 DAT were not significant (geometric means $0.07 \%, 0.35 \%$, and $<0.01 \%$ at 45,410 , and $775 \mathrm{~d}$ after treatment, respectively). A. frigida cover was significantly higher at 775 DAT $(3.05 \%)$ compared with 0 DAT $(1.40 \%)$, while $P$. patagonica was significantly higher at 1140 DAT $(0.98 \%)$ compared to 0,45 , and 410 DAT $(0.09-0.15 \%)$.

Total biomass yields assessed each year averaged 1.6 $\mathrm{Mg} \cdot \mathrm{ha}^{-1}$ over the $3 \mathrm{yr}$ (Table S2). The total biomass was not significantly affected by LWD rate but decreased with time from a mean of $1.74 \mathrm{Mg} \cdot \mathrm{ha}^{-1}$ in the baseline and at 45 DAT to $1.32 \mathrm{Mg} \cdot \mathrm{ha}^{-1}$ at $1140 \mathrm{DAT}$. ANPP was not affected

${ }^{1}$ Available at http://dx.doi.org/10.2111/REM-D-10-00028.s1. 
Table 2. Concentrations of major and minor nutrient elements in the drilling mud applied in the study plots during the $3 \mathrm{yr}$.

\begin{tabular}{|c|c|c|c|c|c|c|c|c|c|c|c|c|c|c|c|}
\hline \multirow[b]{2}{*}{ Parameter } & \multicolumn{3}{|c|}{$\mathrm{N}$} & \multirow[b]{2}{*}{$P$} & \multirow[b]{2}{*}{ K } & \multirow[b]{2}{*}{ S } & \multirow[b]{2}{*}{$\mathrm{Ca}$} & \multirow[b]{2}{*}{$\mathrm{Mg}$} & \multirow[b]{2}{*}{$\mathrm{Na}$} & \multirow[b]{2}{*}{$\mathrm{Fe}$} & \multirow[b]{2}{*}{$\mathrm{Cu}$} & \multirow[b]{2}{*}{$\mathrm{Zn}$} & \multirow[b]{2}{*}{$\mathrm{Mn}$} & \multirow[b]{2}{*}{ B } & \multirow[b]{2}{*}{ Mo } \\
\hline & Total & $\mathrm{NO}_{3}$ & $\mathrm{NH}_{4}$ & & & & & & & & & & & & \\
\hline & $\mathrm{g} \cdot \mathrm{kg}^{-1}$ & ---------- & --------- & -------- & --------. & --------. & ----------. & $-\mathrm{mg} \cdot \mathrm{kg}$ & mud - & ---------- & --------- & ------ & ----- & ------. & ------- \\
\hline Minimum & 1.12 & 0.05 & $<0.01$ & 598 & 2590 & 5886 & 12302 & 5594 & 2195 & 23965 & 23.9 & 104 & 113 & 8.8 & 0.88 \\
\hline Maximum & 5.65 & 808 & 38.45 & 1656 & 4000 & 19883 & 40196 & 10664 & 6727 & 31374 & 113.0 & 182 & 390 & 40.9 & 6.96 \\
\hline Mean & 2.22 & 246 & 9.35 & 889 & 3126 & 13308 & 18614 & 7219 & 4076 & 27252 & 36.8 & 120 & 192 & 26.4 & 3.40 \\
\hline Median & 1.58 & 222 & 3.79 & 773 & 3136 & 13307 & 15518 & 7117 & 3654 & 27186 & 32.2 & 117 & 189 & 27.5 & 3.30 \\
\hline
\end{tabular}

by LWD rate or time elapsed since mud application and averaged $1.1 \mathrm{Mg} \cdot \mathrm{ha}^{-1}$. Standing dead biomass (mean $\left.0.5 \mathrm{Mg} \cdot \mathrm{ha}^{-1}\right)$ and ground litter $\left(0.4 \mathrm{Mg} \cdot \mathrm{ha}^{-1}\right)$ were also not significantly affected by LWD rate. Similarly, there were no significant effects (data not shown) of LWD rate or time of sampling on plant $S, H^{\prime}$, and $E$. These indices averaged 11 $\left(0.25 \mathrm{~m}^{2}\right)^{-1}, 1.9$, and 0.8 , respectively.

\section{Nutrient Concentration in Plant Tissue}

Aboveground Standing Live Biomass. Total N concentration in plant tissue of ANPP (16.3 to $17.7 \mathrm{~g} \cdot \mathrm{kg}^{-1}$ ) was significantly affected by LWD rate; however, the rate effect varied with time elapsed since mud application, as indicated by the significant rate by time interaction (Table S3). The $\mathrm{N}$ concentration increased by $0.4 \%$ for each $1 \mathrm{~m}^{3} \cdot \mathrm{ha}^{-1} \mathrm{LWD}$ rate increment $\left(r^{2}=0.92\right)$ in live biomass samples collected $45 \mathrm{~d}$ after mud application, but there were no significant changes in the concentration measured at later sampling dates (Fig. 1a). At all rates investigated, $\mathrm{N}$ concentrations were lowest (mean $\left.15.1 \mathrm{~g} \cdot \mathrm{kg}^{-1}\right)$ in samples taken 775 and $1140 \mathrm{~d}$ after mud application.

There was a significant rate by time interaction for $\mathrm{P}$ concentration in the live biomass (Table S3), which indicated that LWD effects differed with sampling time. The P concentrations at LWD rates of 40 and $80 \mathrm{~m}^{3} \cdot \mathrm{ha}^{-1}$ were significantly higher than those in the control in samples collected 1140 DAT, but no significant rate effects were detected at earlier sampling times (Fig. 1b). The P concentrations at the 40 and $80 \mathrm{~m}^{3} \cdot \mathrm{ha}^{-1}$ rates were also significantly higher at $1140 \mathrm{DAT}$ compared with concentrations measured in samples taken just before (baseline) or $1 \mathrm{yr}$ after mud application.

Tissue concentrations of $\mathrm{S}, \mathrm{Mg}$, and $\mathrm{Na}$ increased significantly with LWD rate at 45 DAT, but no significant effects were observed at later sampling dates (Table S3; Fig. 1). At all sampling dates, drilling mud rate had no significant effect on $\mathrm{Ca}$ and $\mathrm{K}$ concentrations in the live biomass.

Aboveground Standing Dead Biomass. Elemental concentrations in the standing litter were lower than those in the live biomass, with the exception of $\mathrm{Ca}$ and $\mathrm{Na}$ concentrations, which were $2 \%$ and $44 \%$ higher, respectively, in the standing litter (Table S4). Nitrogen (mean $\left.10 \mathrm{~g} \cdot \mathrm{kg}^{-1}\right), \mathrm{P}\left(808 \mathrm{mg} \cdot \mathrm{kg}^{-1}\right)$ and $\mathrm{K}\left(2012 \mathrm{mg} \cdot \mathrm{kg}^{-1}\right)$ concentrations were not significantly affected by LWD rate, while $\mathrm{N}$ concentration was significantly lower $3 \mathrm{yr}$ after mud application $\left(9.1 \mathrm{mg} \cdot \mathrm{kg}^{-1}\right)$ compared to samples collected 1 yr post-treatment or earlier (10.4$\left.10.9 \mathrm{mg} \cdot \mathrm{kg}^{-1}\right)$. Drilling mud rate effects on tissue concentra-

Table 3. Changes in basal cover with drilling mud rate and sampling time. Probability values in bold indicate significance at $P \leq 0.05$.

\begin{tabular}{|c|c|c|c|c|c|c|}
\hline Treatment & Lichens & Ground litter & Total vegetation & Bare soil & Live club moss & Dead club moss \\
\hline & & & & 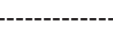 & 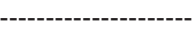 & 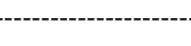 \\
\hline \multicolumn{7}{|c|}{ Rate $\left(\mathrm{m}^{3} \cdot \mathrm{ha}^{-1}\right)$} \\
\hline 0 & $1.76 a^{1}$ & 24.62 & 46.59 & $4.10 \mathrm{~b}$ & 10.49 & 12.42 \\
\hline 15 & $1.07 \mathrm{ab}$ & 25.69 & 46.73 & $4.26 \mathrm{ab}$ & 10.24 & 12.01 \\
\hline 20 & $0.57 a b$ & 24.67 & 46.63 & $3.99 \mathrm{~b}$ & 10.77 & 13.37 \\
\hline 40 & $1.25 \mathrm{ab}$ & 24.58 & 46.03 & $4.85 a b$ & 10.29 & 13.00 \\
\hline 80 & $0.35 \mathrm{~b}$ & 25.54 & 46.62 & $6.12 \mathrm{a}$ & 8.59 & 12.79 \\
\hline \multicolumn{7}{|l|}{ Time $(\mathrm{DAT})^{2}$} \\
\hline 0 & 1.09 & 25.74 & 43.97 & 4.86 & 11.99 & 12.35 \\
\hline 45 & 0.90 & 24.93 & 43.43 & 5.07 & 10.88 & 14.79 \\
\hline 410 & 1.01 & 23.91 & 43.52 & 6.88 & 10.16 & 14.53 \\
\hline 775 & 0.88 & 23.96 & 50.69 & 4.16 & 8.51 & 11.80 \\
\hline 1140 & 1.00 & 26.55 & 52.11 & 2.52 & 8.33 & 9.49 \\
\hline Rate & 0.03 & 0.57 & 0.43 & 0.01 & 0.67 & 0.71 \\
\hline Time & 0.81 & 0.75 & 0.85 & 0.45 & 0.21 & 0.21 \\
\hline Rate $\cdot$ Time & 0.99 & 0.84 & 0.99 & 0.49 & 0.67 & 0.73 \\
\hline
\end{tabular}

${ }^{1}$ Means within a column followed by the same letter are not significantly different according to Tukey's multiple comparison test $(P \leq 0.05)$.

${ }^{2}$ DAT, days after treatment. 
Table 4. Changes in major grass species canopy cover with drilling mud rate. Probability values in bold indicate significance at $P \leq 0.05$.

\begin{tabular}{|c|c|c|c|c|c|c|}
\hline Treatment & B. gracilis & K. macrantha & H. comata & C. montanensis & Carex spp. & P. smithii \\
\hline & & & & & & \\
\hline \multicolumn{7}{|c|}{ Rate $\left(\mathrm{m}^{3} \cdot \mathrm{ha}^{-1}\right)$} \\
\hline 0 & 36.6 & 2.17 & 34.0 & 0.74 & 18.6 & 0.78 \\
\hline 15 & 42.3 & 2.04 & 28.4 & 0.95 & 16.9 & 2.61 \\
\hline 20 & 44.5 & 2.58 & 29.8 & 0.78 & 11.9 & 3.20 \\
\hline 40 & 41.0 & 4.57 & 31.2 & 0.78 & 13.9 & 1.66 \\
\hline 80 & 42.2 & 2.65 & 30.7 & 1.00 & 15.7 & 0.66 \\
\hline \multicolumn{7}{|l|}{ Time $(\mathrm{DAT})^{2}$} \\
\hline 0 & 41.5 & 2.27 & $30.8 a b^{1}$ & $0.71 \mathrm{~b}$ & 16.4 & 1.75 \\
\hline 45 & 43.2 & 3.06 & $31.1 \mathrm{a}$ & $1.23 \mathrm{a}$ & 13.0 & 2.01 \\
\hline 410 & 41.7 & 2.51 & $31.4 \mathrm{a}$ & $0.73 \mathrm{~b}$ & 14.5 & 1.65 \\
\hline 775 & 39.5 & 3.74 & $30.5 \mathrm{~b}$ & $0.71 \mathrm{~b}$ & 16.1 & 1.77 \\
\hline 1140 & 41.4 & 2.28 & $30.2 \mathrm{~b}$ & $0.92 a b$ & 16.8 & 1.50 \\
\hline Rate & 0.31 & 0.27 & 0.43 & 0.17 & 0.27 & 0.17 \\
\hline Time & 0.78 & 0.27 & 0.05 & 0.05 & 0.30 & 0.96 \\
\hline Rate $\cdot$ Time & 0.99 & 0.96 & 0.99 & 0.75 & 0.99 & 0.99 \\
\hline
\end{tabular}

${ }^{1}$ Means within a column followed by the same letter are not significantly different according to Tukey's multiple comparison test $(P \leq 0.05)$.

${ }^{2}$ DAT, days after treatment.

tions of $\mathrm{S}, \mathrm{Mg}, \mathrm{Ca}$, and $\mathrm{Na}$ were significant only in samples taken at 45 DAT, in which the concentrations increased with LWD rate (Fig. 2).

\section{DISCUSSION}

Overall, this study showed no evidence of detrimental effects on important vegetation properties at rates $\leq 20 \mathrm{~m}^{3} \cdot \mathrm{ha}^{-1}$ or $\leq 6 \mathrm{Mg} \cdot \mathrm{ha}^{-1}$ total solids loadings, which are commonly applied in western Canada. Even at the $40 \mathrm{~m}^{3} \cdot \mathrm{ha}^{-1}$ rate, there were no significant negative effects on vegetation attributes. Results from an earlier study (Zvomuya et al. 2008) showed that at LWD rates of 40 and $80 \mathrm{~m}^{3} \cdot \mathrm{ha}^{-1}$, drilling mud application could alter soil micrometeorological properties that may impact on plant growth. Any such impacts, however, were not evident in vegetation measurements from the present study. It is noteworthy that micrometeorological effects in the

Table 5. Changes in canopy cover of major forb species with drilling mud rate and sampling time. Probability values in bold indicate significance at $P \leq 0.05$.

\begin{tabular}{|c|c|c|c|c|c|}
\hline Treatment & E. caespitosus & P. hoodii & A. frigida & S. coccinea & P. patagonica \\
\hline & & & $-----\%$ & & \\
\hline \multicolumn{6}{|c|}{ Rate $\left(\mathrm{m}^{3} \cdot \mathrm{ha}^{-1}\right)$} \\
\hline 0 & 0.12 & 0.87 & 2.81 & 3.22 & 0.09 \\
\hline 15 & 0.70 & 0.35 & 2.50 & 2.95 & 0.33 \\
\hline 20 & 0.08 & 0.92 & 1.77 & 3.92 & 0.54 \\
\hline 40 & 0.11 & 0.73 & 1.70 & 3.87 & 0.54 \\
\hline 80 & 0.11 & 0.84 & 1.58 & 4.02 & 0.54 \\
\hline \multicolumn{6}{|l|}{ Time $(\mathrm{DAT})^{2}$} \\
\hline 0 & 0.56 & 0.70 & $1.40 b^{1}$ & 3.77 & $0.15 \mathrm{c}$ \\
\hline 45 & 0.07 & 0.73 & $1.95 \mathrm{ab}$ & 3.56 & $0.09 \mathrm{bc}$ \\
\hline 410 & 0.35 & 0.67 & $1.89 a b$ & 4.49 & $0.11 \mathrm{bc}$ \\
\hline 775 & $<0.01$ & 0.73 & $3.05 \mathrm{a}$ & 3.29 & $0.66 \mathrm{ab}$ \\
\hline 1140 & 0.16 & 0.87 & $1.95 \mathrm{ab}$ & 2.96 & $0.98 \mathrm{a}$ \\
\hline Rate & 0.01 & 0.74 & 0.51 & 0.34 & 0.77 \\
\hline Time & 0.02 & 0.84 & 0.01 & 0.53 & $<0.0001$ \\
\hline Rate $\cdot$ Time & 0.02 & 0.97 & 0.99 & 0.76 & 0.87 \\
\hline
\end{tabular}

${ }_{1}^{1}$ Means within a column followed by the same letter are not significantly different according to Tukey's multiple comparison test $(P \leq 0.05)$.

${ }^{2}$ DAT, days after treatment. 


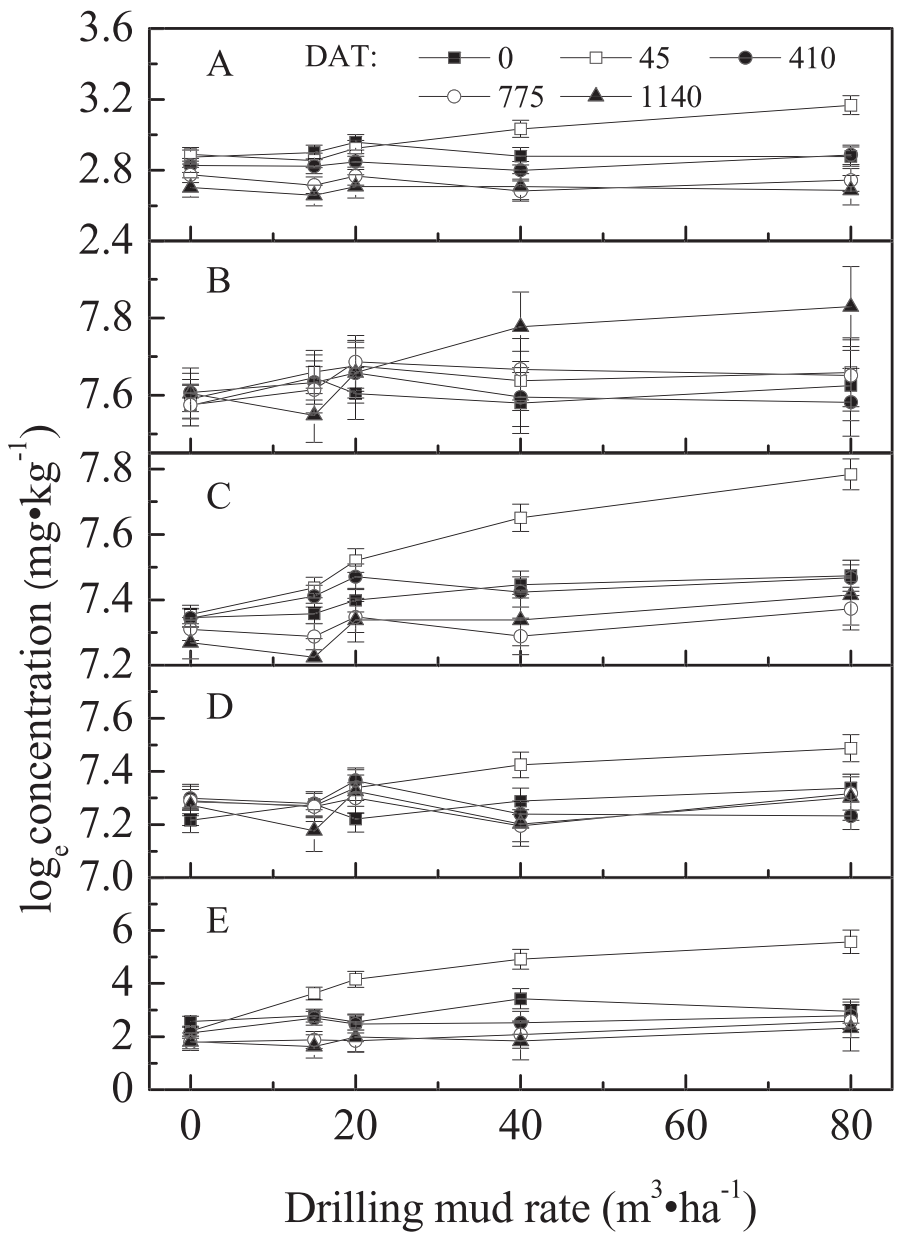

Figure 1. Effects of drilling mud rate and sampling time (days after treatment [DAT]) on tissue elemental concentration in the live biomass (A: nitrogen; B: phosphorus; C: sulfur; D: magnesium; and E: sodium).

aforementioned study were monitored for less than 2 mo, thereby precluding assessment of persistent effects over an extended period. Other evidence (Zvomuya et al. 2009) indicates that drilling mud application at the $80 \mathrm{~m}^{3} \cdot \mathrm{ha}^{-1}$ rate can impede near-saturated hydraulic conductivity, ostensibly due to clogging of conductive macropores in the receiving soil. Water that fails to infiltrate and instead remains on the soil surface is subject to runoff or evaporation losses, and is therefore not available for plant uptake or soil storage. Under the semi-arid conditions of the current study site, this would be expected to adversely affect nutrient uptake, plant growth, and ANPP. However, such effects were not evident, perhaps because the hydrological effects did not persist beyond $1 \mathrm{yr}$ following drilling mud application. High rainfall $(332 \mathrm{~mm})$ in 2005, particularly the $27 \mathrm{~mm}$ recorded within a day of mud application, meant that much of the mud was washed off the vegetation before it had enough time to impart any adverse effect on the vegetation.

The decrease in lichen cover at the $80 \mathrm{~m}^{3} \cdot \mathrm{ha}^{-1} \mathrm{LWD}$ rate compared with the control was probably due to smothering of lichens by the mud. With the disappearance of the lichen cover, more soil was exposed, explaining the significant increase in bare ground at the highest LWD rate. A high lichen cover is considered beneficial to the semi-arid grasslands as it contributes

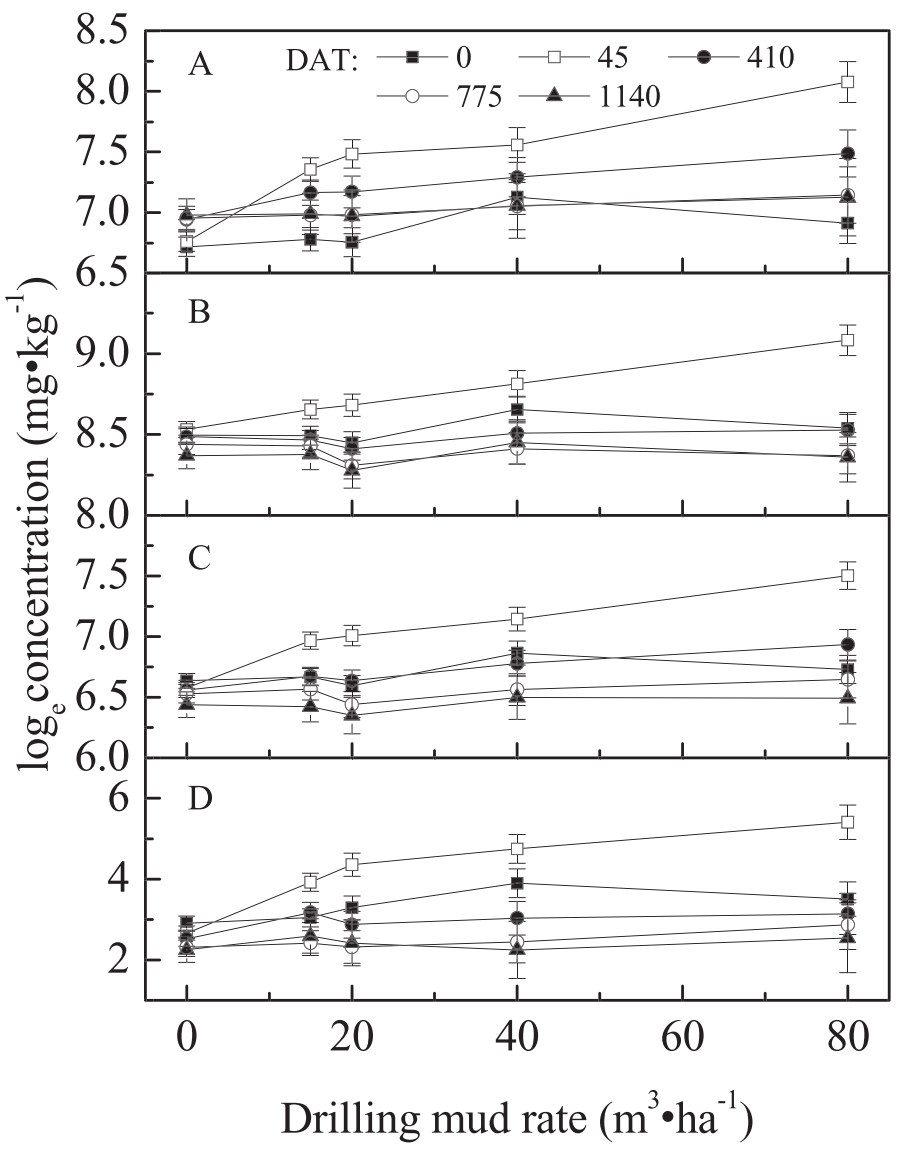

Figure 2. Effects of drilling mud rate and sampling time (days after treatment [DAT]) on tissue elemental concentration in the standing dead biomass (A: sulfur; B: calcium; C: magnesium; and D: sodium).

to stabilization of the soil, improvement of water infiltration, and nitrogen fixation by blue-green algae (Willms et al. 2002).

The observed LWD rate effects on tissue $\mathrm{N}, \mathrm{S}$, and $\mathrm{Mg}$ concentrations $45 \mathrm{~d}$ after mud application is consistent with the plant availability of these elements once applied to the soil. Unlike $\mathrm{P}$ addition in the LWD, which had no immediate effect (i.e., within the first year), these elements do not form products, in the mud or in the soil, that are only slowly available. Thus, they become immediately available for uptake by plants as soon as they are applied to the soil. Secondly, since LWD leaves the mud and its constituent elements on the surface, the elements have to be translocated into the root zone before they can be taken up by plants. Elements such as N, S, and Mg, a large proportion of which remains in a soluble form, are therefore more easily transported with percolating water to the root zone. Because there is no slowly-available form of these elements added with the mud, their effects on tissue concentrations do not persist beyond 1 yr. By contrast, $\mathrm{P}$ forms various insoluble or slowly-available compounds or complexes in the soil, and therefore moves more slowly down the profile to the root zone. This explains why significant $\mathrm{P}$ effects in plant tissue are only observed $3 \mathrm{yr}$ after LWD. Phosphorus is also strongly adsorbed by soil constituents, which makes it more slowlyavailable for plant uptake.

Although median total $\mathrm{N}$ loadings ranged from $28.9 \mathrm{~kg} \cdot \mathrm{ha}^{-1}$ at the $15 \mathrm{~m}^{3} \cdot \mathrm{ha}^{-1} \mathrm{LWD}$ rate to as much as $154 \mathrm{~kg} \cdot \mathrm{ha}^{-1}$ at the 
$80 \mathrm{~m}^{3} \cdot \mathrm{ha}^{-1}$ rate, treatment differences in biomass yield and species diversity were not observed. This was not surprising, considering that only $\sim 15 \%$ of applied $\mathrm{N}$ was readily available (predominantly $\mathrm{NO}_{3}-\mathrm{N}$ ). Similar $\mathrm{N}$ fertilization effects on mixed-grass prairie have been reported elsewhere. For example, Samuel and Hart (1998) found no increase in biomass production following application of up to $34 \mathrm{~kg} \cdot \mathrm{N} \cdot \mathrm{ha}^{-1}$ to mixed-grass rangeland in southeast Wyoming. By contrast, many other studies on native range in the central and northern Great Plains have reported increases in biomass production in response to very low to very high $\mathrm{N}$ rates (e.g., Black and Wight 1979; Power 1985; Jacobsen et al. 1996). A few others have reported changes in species diversity in response to $\mathrm{N}$ application (Goetz 1969; Rauzi and Fairbourn 1983; Samuel and Hart 1998). For example, in a study on rangeland in southwestern North Dakota, three annual applications of up to $112 \mathrm{~kg} \cdot \mathrm{N} \cdot \mathrm{ha}^{-1}$ reduced cover of B. gracilis (H.B.K.) Griffith's and increased cover and density of $P$. smithii (Rydb.) A. Love and Artemisia spp. (Goetz 1969).

Another study examining the response of more than 900 plant species to $\mathrm{N}$ fertilization in North American terrestrial ecosystems demonstrated a significant loss in species diversity, including that of native grasses, regardless of their initial abundance, as production increased with $\mathrm{N}$ application (Suding et al. 2005). The difference in response between these and our study is not surprising: in these past studies, fertilizer was applied as a nutrient source containing no other potentially detrimental additives. By comparison, the nutrients in our study were contained in a matrix (drilling mud) that could adversely affect plant growth through, for example, coatings on the vegetation canopy that interfere with light interception and absorption and $\mathrm{CO}_{2}$ uptake. Reduced photosynthesis and productivity due to particulate coverings on plant canopies are well documented and have been attributed to leaf shading and interference with stomatal activity (Farmer 1993; Hirano et al. 1995; Sharifi et al. 1997; Glenn et al. 2001). Hirano et al. (1995) further noted that additional absorption of incident radiation by the chemically inert dust tested in their study increased leaf temperature and consequently, altered photosynthetic rate and increased transpiration. Such effects have been found to be significant in situations, such as in the present study, where the fine particles are deposited during the day when stomata are open, thus plugging the stomata (Thompson et al. 1984) and preventing them from closing during dark hours (Flückiger et al. 1979). The effects are likely to be greater in the case of drilling mud, which, unlike dusts, covers the leaf surfaces with a crust. It is possible that such adverse, confounding effects may have counteracted any yield benefits from the nutrient additions.

Additionally, application of $\mathrm{N}$ and other elements/additives within the same treatment varied by year and sometimes within a given year, possibly resulting in high variability in vegetation response, and therefore possibly a reduced power to detect significant differences. Perhaps more important is the possibility that much of the inorganic $\mathrm{N}$ added with the mud was immobilized by microorganisms in the organic matter-rich surface soil, which has low native $\mathrm{N}$ reserves. Rapid immobilization of applied $\mathrm{N}$ in mixed prairie soil is welldocumented (Risser and Parton 1982; Willms and Jefferson 1993). Power (1972) reported that $\mathrm{N}$ immobilization by plant roots, soil organic matter, and microbial cells plus gaseous losses accounted for as high as $37 \%\left(200 \mathrm{~kg} \cdot \mathrm{N} \cdot \mathrm{ha}^{-1}\right)$ of $\mathrm{N}$ applied $\left(540 \mathrm{~kg} \cdot \mathrm{N} \cdot \mathrm{ha}^{-1}\right)$ in an Agropyron-Stipa-Bouteloua community. Furthermore, while it is well established that soil moisture and temperature regimes play a critical role in regulating $\mathrm{N}$ transformations (Power 1967) and productivity (Willms and Jefferson 1993) in grassland soils, it has been shown in other studies that $\mathrm{N}$ application alone is unlikely to greatly increase biomass yield if moisture is limiting (Smika et al. 1965). In our study, drilling mud (hence $N$ ) applications were typically followed by long, dry periods, which are typical of the Dry Mixedgrass natural subregion of Alberta, and this might have contributed to low availability of $\mathrm{N}$ for plants, thus resulting in no biomass yield increase.

The lower concentrations of nutrient elements measured in the standing dead biomass vs. that in live biomass were expected and have been reported in other studies (e.g., Sundriyal and Joshi 1992). Towards the end of the growing season, nutrients are translocated from aboveground biomass to roots and rhizomes (Sundriyal and Joshi 1992), resulting in lower concentrations in the standing dead biomass compared with live, current season biomass. Additionally, nutrients within dead biomass from the previous season may be leached out by precipitation and translocated to new tissue (Dowding et al. 1981).

The drilling mud used in this study presents no toxicity concern to grazing animals. Trace element concentrations in the mud (Table S1) were low and did not significantly raise concentrations in the soil or plant tissue relative to the control (data not presented). Total lifetime loadings (per ha), from all disposal methods, allowed by Alberta regulations in order to protect animals and flora are $10 \mathrm{~kg}$ boron (B), $3 \mathrm{~kg}$ cadmium (Cd), $200 \mathrm{~kg}$ chromium (Cr), $400 \mathrm{~kg}$ copper $(\mathrm{Cu}), 200 \mathrm{~kg}$ lead $(\mathrm{Pb}), 50 \mathrm{~kg}$ nickel (Ni), and $600 \mathrm{~kg}$ zinc (Zn; Alberta Energy and Utilities Board 1996). In this study, loadings of these trace elements were small even at the highest LWD rate $\left(80 \mathrm{~m}^{3} \cdot \mathrm{ha}^{-1}\right)$ at which only $2.7 \mathrm{~kg} \mathrm{~B}, 0.2 \mathrm{~kg} \mathrm{Cd}, 2.3 \mathrm{~kg} \mathrm{Cr}, 3.8 \mathrm{~kg} \mathrm{Cu}, 2.5 \mathrm{~kg}$ $\mathrm{Pb}, 4.0 \mathrm{~kg} \mathrm{Ni}$, and $11.1 \mathrm{~kg} \mathrm{Zn}$ were added per ha.

\section{IMPLICATIONS}

Drilling mud application at rates commonly applied in western Canada had no significant effect on most native vegetation properties measured in this study. Exceptions were bare ground, which increased, and lichen cover, which decreased at the $80 \mathrm{~m}^{3} \cdot \mathrm{ha}^{-1}$ rate relative to the control. Our results also indicated significant LWD effects on plant tissue chemistry, specifically $\mathrm{N}, \mathrm{P}, \mathrm{Mg}$, and S concentrations. The more soluble nutrient elements, $\mathrm{N}, \mathrm{Mg}$, and $\mathrm{S}$, increased significantly with increasing LWD rate in samples taken $45 \mathrm{~d}$ after drilling mud application; however, no significant LWD effects were detected after 1 yr. Tissue $\mathrm{P}$ concentration, on the other hand, showed significant LWD rate effects only after $3 \mathrm{yr}$ since LWD. Nonetheless, these changes in tissue chemistry were not associated with significant changes in the biomass yield or species composition.

Overall, our results indicate that proper, one-time applications of water based drilling mud at rates $\left(\leq 20 \mathrm{~m}^{3} \cdot \mathrm{ha}^{-1}\right)$ commonly applied in western Canada are unlikely to cause significant adverse effects on native prairie vegetation. This has 
important implications on the management of drilling waste on native prairie in this and other regions. When current Alberta regulations, as embodied in Directive 50, were promulgated in 1993 and revised in 1996 (Alberta Energy and Utilities Board 1996), they represented the best current knowledge and practices undertaken in the Province at the time, with the understanding that the regulations would be subject to review and modification as newer knowledge became available. Our results provide regulators and the petroleum industry with the first science-based information that can be used in the review of current regulations. In the event that such a review leads to relaxation of some of the restrictions on LWD, this could significantly reduce the ecological footprint associated with the mix-bury-cover disposal option (which involves mixing the drilling solids with clean soil and burying the mixed material in an unlined pit). While the practice of LWD has not been entirely satisfactory, in other regards, largely due to improper application methods leading to overapplication, our data confirm that with proper application, LWD can have minimal adverse effects on native prairie vegetation.

\section{ACKNOWLEDGMENTS}

We thank the CFB Suffield Base Commander for providing the field site and allowing access to the military base. The contributions of Paul DeMaere, Dan Yagos, Bonnie Tovell, and Clarence Gilbertson toward field and laboratory work are greatly appreciated.

\section{LITERATURE CITED}

Alberta Energy and Utilities Board. 1996. Directive 50: drilling waste management. Calgary, AB, Canada: Alberta Energy and Utilities Board.

BLACK, A. L., AND J. R. WIGHT. 1979. Range fertilization: nitrogen and phosphorous uptake and recovery over time. Journal of Range Management 32:349-353.

Bloys, B., N. Davis, B. Smolen, L. Balley, P. Reid, L. Fraser, and M. Hodder. 1994. Designing and managing drilling fluids. Oilfield Review 6:33-43.

Daubenmire, R. 1968. Plant communities: a textbook of plant synecology. New York, NY, USA: Harper \& Row Publishers.

Dowding, P., F. S. Chapin III, F. E. Wielgolaski, and P. Kilfeather. 1981. Nutrients in tundra ecosystems. In: L. C. Bliss, W. Heal, and J. J. Moore [EDS.]. Tundra ecosystems: a comparative analysis. Cambridge, UK: Cambridge University Press. p. 647-683.

Environment Canada. 2007. Conservation of Canadian prairie grasslands: mixed prairie. Available at: http://www.mb.ec.gc.ca/nature/whp/prgrass/df03s33.en. html. Accessed 17 February 2011.

Farmer, A. M. 1993. The effects of dust on vegetation: a review. Environmental Pollution 79:63-75.

FlüCKIGER, W., J. J. OeRTLI, AND H. FlücKIger. 1979. Relationship between stomatal diffusive resistance and various applied particle sizes on leafsurfaces. Zeitschrift fur Pflanzenphysiologie 91:173-175.

Glenn, D. M., G. J. Puterka, S. R. Drake, T. R. Unruh, A. L. Knight, P. Baherle, E. Prado, and T. A. Baugher. 2001. Particle film application influences apple leaf physiology, fruit yield, and fruit quality. Journal of the American Society for Horticultural Science 126:175-181.

GoETZ, H. 1969. Composition and yields of native grassland sites fertilized at different rates of nitrogen. Journal of Range Management 22:384-390.

Hirano, T., M. Kiyota, and I. Aiga. 1995. Physical effects of dust on leaf physiology of cucumber and kidney bean plants. Environmental Pollution 89:255-261.

Jacobsen, J. S., S. H. Jorbeer, H. A. R. Houlton, and G. R. Carlson. 1996. Nitrogen fertilization of dryland grasses in the Northern Great Plains. Journal of Range Management 49:340-345.
Littell, R. C., G. A. Milliken, W. W. Stroup, and R. D. Wolfinger. 1996. SAS System for Mixed Models. Cary, NC, USA: SAS Institute Inc.

Loughin, T. M., M. P. Roediger, G. A. Milliken, And J. P. Schmidt. 2007. On the analysis of long-term experiments. Journal of the Royal Statistical Society, Series A: Statistics in Society 170:29-42.

NefF, J. M., N. N. Rabalais, and D. F. Boesch. 1987. Offshore oil and gas development activities potentially causing long-term environmental effects. In: D. F. Boesch and N. N. Rabalais [EDS.]. Long-term effects of offshore oil and gas development. London, UK: Elsevier Applied Science Publishers. p. 149-174.

PoWER, J. F. 1967. The effect of moisture on fertilizer nitrogen immobilization in grasslands. Soil Science Society of America Proceedings 31:223-226.

PoWER, J. F. 1972. Fate of fertilizer nitrogen applied to Northern Great Plains rangeland ecosystem. Journal of Range Management 25:367-371.

Power, J. F. 1985. Nitrogen- and water-use efficiency of several cool-season grasses receiving ammonium nitrate for 9 years. Agronomy Journal 77:189-192.

Rauzi, F., and M. L. Falrbourn. 1983. Effects of annual applications of low N fertilizer rates on a mixed grass prairie. Journal of Range Management 36:359-362.

Risser, P. G., and W. J. Parton. 1982. Ecosystem analysis of the tallgrass prairie: nitrogen cycle. Ecology 63:1342-1351.

Samuel, M. J., and R. H. Hart. 1998. Nitrogen fertilization, botanical composition and biomass production on mixed-grass rangeland. Journal of Range Management 51:408-416.

SAS Institute. 2005. SAS OnlineDoc, version 9.1.3. Cary, NC, USA: SAS Institute Inc.

Sharifi, M. R., A. C. Gibson, and P. W. Rundel. 1997. Surface dust impacts on gas exchange in Mojave Desert shrubs. Journal of Applied Ecology 34:837-846.

SMika, D. E., H. J. HAAS, ANd J. F. Power. 1965. Effects of moisture and nitrogen fertilizer on growth and water use by native grass. Agronomy Journal 57:483-486.

Suding, K. N., S. L. Collins, L. Gough, C. Clark, E. E. Cleland, K. L. Gross, D. G. Milchunas, and S. Pennings. 2005. Functional- and abundance-based mechanisms explain diversity loss due to $\mathrm{N}$ fertilization. Proceedings of the National Academy of Sciences of the United States of America 102:4387-4392.

SundRIYAL, R. C., AND A. P. Joshi. 1992. Annual nutrient budget for an Alpine Grassland in the Garhwal Himalaya. Journal of Vegetation Science 3:21-26.

Thompson, J. R., P. W. Mueller, W. Flückiger, and A. J. Rutter. 1984. The effects of dust on photosynthesis and its significance for roadside plants. Environmental Pollution Series A 34:171-190.

Ukeles, S. D., and B. Grinbaum. 2004. Drilling fluids. In: Kirk-Orthmer [ed.]. KirkOthmer encyclopedia of chemical technology. New York, NY, USA: John Wiley and Sons, Inc. DOI:10.1002/0471238961.0418091203120118.a01.pub2.

[USEPA] US Environmental Protection Agency. 1996. Acid digestion of sediments, sludges, and soils, Method 3050B, Revision 2. Washington, DC, USA: USEPA, Office of Solid Waste and Emergency Response. Available at: http://www.epa. gov/epaoswer/hazwaste/test/3050b.pdf. Accessed 17 February 2011.

VEIL, J. A. 1997. Costs for off-site disposal of nonhazardous oil field wastes: salt caverns versus other disposal methods. Argonne, IL, USA: National Petroleum Technology Office. DOE/BC/W-31-109-Eng-38-2, prepared for U.S. Department of Energy.

Willms, W. D., J. F. Dormaar, B. W. Adams, and H. E. Douwes. 2002. Response of the mixed prairie to protection from grazing. Journal of Range Management 55:210-216.

Willms, W. D., And P. G. Jefferson. 1993. Production characteristics of the mixed prairie: constraints and potential. Canadian Journal of Animal Science 73:765-778.

Zvomuya, F., F. J. Larney, P. R. Demaere, and A. F. Olson. 2009. Hydraulic properties of a sandy loam soil following spent drilling mud application on native prairie. Soil Science Society of America Journal 73:1108-1112.

Zvomuya, F., F. J. Larney, S. M. McGinn, A. F. Olson, and W. D. Willims. 2008. Surface albedo and soil heat flux changes following drilling mud application to a semiarid mixed-grass prairie. Soil Science Society of America Journal 72:1217-1225. 